\title{
Translation and language learning: AlfraCovalt as a tool for raising learners' pragmalinguistic and sociopragmatic awareness of the speech act of requesting ${ }^{1}$
}

\author{
Josep R. Guzman (GUZMAN, Josep R.) \\ Professor Doutor da Universitat Jaume I, Castellón, Espanha \\ guzman@trad.uji.es \\ Eva Alcón (ALCÓN, Eva) \\ Professora Doutora da Universitat Jaume I, Castellón, Espanha \\ alcon@ang.uji.es
}

\begin{abstract}
Interlanguage pragmatic research has shown that speech act categories and their realisation strategies are found across languages. However, they do not apply to all languages in the same way. Leech (1983) and Thomas (1983) account for this fact by dividing pragmatics into two components: pragmalinguistics and sociopragmatics. When dealing with pragmatics we should consider knowledge of the means to weaken or strengthen the force of an utterance (i.e. pragmalinguistic knowledge) and knowledge of the particular means that are likely to be most successful for a given socio-cultural context (i.e. sociopragmatic knowledge). In this paper we will argue for a reconsideration of translation as a communicative-pragmatic practice in foreign language settings. First, we will provide a historical outline of how translation has been used in language teaching. Secondly, a range of translation activities which may benefit learners' development of pragmalinguistic and sociopragmatic awareness are suggested. Thirdly, we will make a number of suggestions as to how AlfraCovalt might be used to improve learners' pragmatic awareness.
\end{abstract}

Keywords: pragmatic awareness, teaching speech acts, cross linguistics analysis

\section{Resumo}

Estudos em pragmática da interlíngua têm indicado que as categorias de atos de fala e suas estratégias de realização ocorrem em todas as línguas. Entretanto, não se aplicam da mesma maneira em cada língua. Para explicar esse fenômeno, Leech (1983) e Thomas (1983) dividem a pragmática em duas componentes: pragmalinguística e sociopragmática. Ao lidar com a pragmática, devem-se levar em consideração os meios que podem enfraquecer ou fortalecer a força do enunciado (i.e. conhecimento

\footnotetext{
${ }^{1}$ Research for this article was funded by a grant from the Ministerio de Educación y Ciència and FEDER for the project HUM2006-11524, and HUM2004-04435/FILO, and Bancaixa P1-1B2008-59.
} 
pragmalinguístico) e o conhecimento dos meios específicos que terão melhores resultados em um determinado contexto sociocultural (i.e. conhecimento sociopragmático). Neste artigo, argumentamos a favor da reconsideração da tradução como uma prática comunicativo-pragmática em contextos de línguas estrangeiras. Primeiro, fornecemos um breve histórico de como a tradução tem sido utilizada no ensino de línguas. Depois, sugerimos uma gama de atividades de tradução que podem beneficiar a aquisição da consciência pragmalinguística e sociopragmática dos aprendizes. Por último, indicamos como o programa AlfraCovalt pode ser utilizado para melhor desenvolver a consciência pragmática do aprendiz.

Palavras-chave: consciência pragmática, ensino de atos de fala, análise crosslinguística

\section{Introduction}

Research in interlanguage pragmatics (ILP) has focused on describing and explaining learners' use, perception and acquisition of second language (L2) pragmatic ability both in second and foreign language contexts. Given its closeness to crosscultural pragmatics, research on learners' use and perception has taken the form of comparative studies, the main focus being on speech acts. In these studies, as reported by Bardovi-Harlig (2001), it has been shown that native speakers (NSs) and non-native speakers (NNSs) appear to differ not only in the way they use speech acts, but also in aspects of content and form. Studies by Bardovi-Harlig and Dörney (1998), Takahashi (1996) and Bardovi-Harlig and Hartford (1996) also illustrate that variables such as length of residence (OLSHTAIN; BLUM-KULKA 1985), level of proficiency (KOIKE, 1989) or the learning environment (BARDOVI-HARLIG; DÖRNYEI, 1998; NIEZGODA; RÖVER, 2001) are decisive factors with respect to perception of appropriate speech acts.

Learner's use and perception of speech acts is a relevant issue in the field of translation. Nobody would doubt that translating is not a linguistic procedure, but an act of communicating across cultures. According to House (forthcoming), translating always involves both languages and cultures because they are inextricably intertwined. Thus, translation could be defined as communication across cultures, which in turn involve using linguistic resources for conveying communicative acts and interpersonal meanings, while paying attention to the social perceptions underlying participants' interpretation and performance of communicative acts. Among the different speech 
acts, the speech act of requesting has been widely examined in interlanguage pragmatics (ILP) research. Considering Searle's $(1969 ; 1976)$ classification of illocutionary acts (i.e., representatives, directives, expressives, commissives and declarations), it can be claimed that requests fall under the second category, that of directives, which has been regarded as "attempts by the speaker to get the hearer to do something” (SEARLE, 1979, p. 13). More specifically, Trosborg (1995, p. 187) defines the speech act of requesting as "an illocutionary act whereby a speaker (requester) conveys to a hearer (requestee) that he/she wants the requestee to perform an act which is for the benefit of the speaker". Taking this fact into account, that is, the speaker imposes and exerts his/her influence over the hearer in order to obtain his/her intentions, the speech act of requesting has been considered an impositive exhortative act and one of the most face-threatening speech acts according to Brown and Levinson's (1987) politeness theory.

Given the impositive face-threatening nature of this speech act, the speaker may mitigate it by employing particular modification devices that soften his/her requests when invading the hearer's territory. Therefore, having knowledge of these devices would increase the speaker's use of appropriate requests in different contextual situations to a great extent, which in turn would contribute to improve his/her overall pragmatic competence in the target language. In fact, existing descriptions of this particular speech act differentiate two main subcomponents: the request head act, and those peripheral modification devices that accompany it. Therefore, in order to have a more complete picture of their total request performance, there is a need to pay closer attention to whether learners modify their requests, and which modifiers they employ to accompany this speech act. To that end, we need to be aware of the wide range of modification items employed with the speech act of requesting which have already been included in several classifications (HOUSE; KASPER, 1981; TROSBORG, 1995; HILL, 1997; ACHIBA, 2003).

The question addressed in this paper is whether and how translation can be applied to develop learners' pragmatic awareness of the speech act of requesting. To answer this question in this paper we will first provide a historical outline of how translation has been used in foreign language teaching. Secondly, we will raise the need to focus on pragmatics and review research dealing with learners' pragmatic awareness. Thirdly, we will illustrate how AlfraCovalt is operated and make a number of 
suggestions as to how AlfraCovalt might be used to improve learners' pragmatic awareness of the speech act of requesting.

\section{Translation in foreign language teaching}

Translation has a long tradition in foreign language contexts. The basis of the grammar translation method consisted of translation from the foreign language and learning grammar rules and vocabulary through the translation of disconnected sentences. However, the direct method movement rejected the use of translation as a teaching technique and emphasized the importance of the spoken mode in foreign language teaching. Although criticism of the use of translation in foreign language teaching and learning continued at the beginning of the twentieth century, such criticiticsm was emphasized with the advent of Audiolingual methodology, which was based on the assumption that oral communication is the main objective of language learning. The opposition of translation as a teaching technique was based on the belief that the mother tongue would prevent the learning of the target language. Finally, within the communicative approach the controversy about using translation in the language classroom is not settled. As far as the principles of communicative language teaching (CLT), there seems to be a consensus on focussing on learners' development of communicative competence, as well as on the principle that communication is both an end and a means towards language learning. Concerning the former principle, speech act theory contributed to the CLT content by designing functional-notional syllabi, which in turn influenced Hymes's (1972) notion of communicative competence. Hymes's original definition of communicative competence, which has been taken into account in several pedagogically communicative competence models (ALCÓN, 2000; BACHMAN, 1990; CANALE, 1983; CANALE; SWAIN, 1980; CELCE-MURCIA et al., 1995), have influenced the selection of the content of CLT, being pragmatics a key component. However, although pro-translation voices suggest using translation in CLT as a technique to raise awareness of contrasts between native and foreign language pragmatic competence, translation is often not related to the desired principles of CLT. In our opinion, the problem seems to be that in evaluating translation as a technique to increase learners' pragmatic competence, only pragmalinguistic is considered while 
sociopragmatic issues are neglected. The emphasis on pragmalinguistic issues results, as reported by House (in press), in failure to exploit the pedagogic usefulness of translation as a complex cross-linguistic activity. However, in line with House (in press), we suggest that the strong pragmatic component in translation makes it potentially useful in raising learners' pragmatic awareness, an issue that has motivated current research in the field of interlanguage pragmatics.

\section{Pragmatic awareness and language learning}

Analysing language use in context has provided language teachers and learners with a research-based understanding of the language forms and functions that are appropriate to the many contexts in which a language may be used. From this perspective, research in cross-cultural pragmatics has provided information on the interactive norms in different languages and cultures. Cross-cultural studies with a focus on speakers' pragmatic performance aim to determine whether the same speech act can be found in different cultures, and if so, to what extent it is performed. Likewise, explanations that account for those differences are provided. Among them, pragmatic transfer at the level of formal, semantic and speakers' perception of contextual factors seem to explain some of the differences between L1 and L2 speakers' use of the language. In addition, research from an interlanguage perspective takes into account acquisitional rather than contrastive issues, but in line with cross-cultural studies, it has focused on routines and pragmalinguistic realisations of different speech acts. A wide amount of studies now exist with a focus on request realisations (HASSALL, 1997; LI, 2000; ROSE, 2000, among many others). Other speech acts that have received some attention on the part of scholars may be refusals (FÉLIX-BRASDEFER, 2004), compliments (ROSE; NG, 2001), and apologies (TROSBORG, 1995). We may also find exceptional studies in which sociopragmatic factors have been dealt with, but they usually refer to descriptions of situations presented to learners so that they acknowledge the most appropriate routine (LORENZO-DUS, 2001).

Although the sociopragmatic component has received less attention in interlanguage pragmatics, there is no doubt that sociopragmatics is relevant in L2 pragmatic development. On that account, Brown and Levinson's (1987) politeness 
variables - namely those of power, distance, and ranking of imposition - and Scollon and Scollon's (1995) suggested politeness frameworks on the basis of face relationships have been used as a point of departure when dealing with pragmatics in foreign language learning and teaching. For instance, Scollon and Scollon's framework is considered in Safont's (2005) study devoted to examining the extent to which explicit instruction on learners' use of request formulae throughout one semester affected their use of peripheral modification devices. The training sessions consisted of description, explanation, discussion and practice on requests in context, and data were collected by means of a pre-test and post-test distributed before and after the instructional period. Results showed a positive effect of explicit instruction, since the use of the awarenessraising and production tasks employed in the study favoured learners' appropriate use of request peripheral modification devices after the treatment although, as claimed by the author, these elements had not been taught explicitly. Another example can be found in Martinez Flor (forthcoming). The author examined the effectiveness of an inductive-deductive teaching approach on learners' appropriate use of request modifiers in different situations that varied according to the three sociopragmatic factors described in Brown and Levinson's (1987) politeness theory, namely those of social distance, power and degree of imposition. Results from this study indicated that, after being engaged in the instructional period, learners: i) used a greater number of request modifiers; ii) made use of a higher number of both internal and external modifiers; and iii) employed all different subtypes of internal and external modifiers, thus, including a wider variety of mitigating devices in learners' requestive behaviour.

In addition, pragmatic awareness seems to be particularly relevant in foreign language learning. Research on ILP has demonstrated that, in contrast to native speakers, who may not need to recognise speech act type consciously, foreign language learners' attention to pragmatic issues seems to be important due to the input difficulties found in foreign language contexts for pragmatic learning. Alcón and Safont (2008) illustrate how several investigations draw on Schmith's (1993, 2001) noticing hypothesis to address awareness-raising as an approach to the teaching of pragmatics. These authors also point out that the studies conducted by Rose (2000) Grant and Starks (2001), Washburn (2001), and Alcón (2005) were motivated by the assumption that audiovisual input provides ample opportunities to address all aspects of language use in a variety of contexts. In addition, audiovisual input is reported to be useful to expose 
learners to the pragmatic aspects of the target language. Finally, the authors suggest that pragmatic judgment tasks based on audiovisual discourse analysis are useful to prepare learners for communication in new cultural settings.

From this perspective, corpora created and built with translations from audiovisual texts can be used to increase learners' pragmatic awareness. As stated by various scholars, learners' pragmatic awareness manifested in their ability to recognize and identify speech act types is limited. For instance, Kasper's (1984) investigation of the pragmatic comprehension of German-speaking English learners, suggested that failure to comprehend the illocutionary force of speech acts could be explained by learners' inability to produce those illocutionary devices in nonconventional indirect speech acts. In addition, the effect of language proficiency on learners' pragmatic awareness has been examined by Koike (1996), Cook and Liddicoat (2002) and García (2004) pointing out learners' proficiency-related differences in the identification of speech acts. In our opinion, contextual knowledge and linguistic ability should be viewed as complementing variables that interact with each other in the comprehension of L2 culture. From this point of view, using translation in foreign language classrooms could be used as a first step to raise learners' sociopragmatic and pragmalinguistic awareness. As we will illustrate next, teaching particular pragmatic features, such as requests, can be achieved by means presenting learners with contextualised examples of requests in translation and using AlfraCovalt together with and an inductive-deductive teaching approach.

\section{Using AlfraCovalt to increase learners' pragmatic awareness of the speech act of requesting}

The pragmatic feature selected to illustrate how to use AlfraCovalt to increase learners' pragmatic awareness is the speech act of request. Trosborg (1995), Sifianou (1999), Márquez Reiter (2000), and Safont (2005) among others, have claimed that requests consist of two parts, (i) the core request or head act, and (ii) the peripheral elements (see Safont, forthcoming, for a detail explanation of the speech act of request). On the one hand, the head act is the main utterance which has the function of requesting and can stand by itself. On the other hand, the peripheral elements are additional items 
which may follow and/or precede the request head act. They do not change the propositional content of the request head act, but rather serve to either mitigate or aggravate its force. Since request modifiers accompany the request head act with the purpose of varying politeness levels and decreasing threatening conditions, they have notable importance when dealing with learning how to request. For the present study we followed Trosborg's (1995) typology of request realisation strategies (Table1) and the typology of peripheral request modification devices suggested by Alcón et al. (2005) and described in Table 2. An adaptation of Sifianou's taxonomy (1999) and the analysis of Spanish EFL learners' oral production data of request modification devices (MARTÍNEZ-FLOR; USÓ, 2006) was taken into account in the design of the taxonomy provided in table 2. Moreover, Brown and Levinson's (1987) sociopragmatic factors, summarised in Table 3, were also taken into account.

\begin{tabular}{|c|c|c|}
\hline \multicolumn{3}{|c|}{ REQUEST REALISATION STRATEGIES } \\
\hline Indirect & Hints: Statement & I have to be at the airport in half an hour \\
\hline \multirow{4}{*}{$\begin{array}{l}\text { Conventionally } \\
\text { Indirect (hearer- } \\
\text { based) }\end{array}$} & $\begin{array}{l}\text { Ability: Could you...?/ Can } \\
\text { you...? }\end{array}$ & Can you lend me your car? \\
\hline & Willingness: Would you...? & Would you lend me your car? \\
\hline & Permission: May I...? & May I borrow your car? \\
\hline & $\begin{array}{l}\text { Suggestory formulae: How } \\
\text { about...? }\end{array}$ & How about lending me your car? \\
\hline \multirow{3}{*}{$\begin{array}{c}\text { Conventionally } \\
\text { Indirect (speaker- } \\
\text { based) }\end{array}$} & Wishes: I would like... & I would like to borrow your car \\
\hline & $\begin{array}{l}\text { Desires/ needs: I want/ need } \\
\text { you to... }\end{array}$ & I want you to lend me your car \\
\hline & $\begin{array}{l}\text { Obligation: You must.../You } \\
\text { have to... }\end{array}$ & You must lend me your car \\
\hline \multirow[t]{3}{*}{ Direct } & Performatives: I ask you to... & I ask you to lend me your car \\
\hline & Imperatives & Lend me your car \\
\hline & Elliptical phase & Your car \\
\hline
\end{tabular}

Table 1: Trosborg's typology (1995)

\begin{tabular}{|l|l|l|l|}
\hline TYPE & SUB-TYPE & EXAMPLE \\
\hline \multirow{3}{*}{ Openers } & & $\begin{array}{l}\text { Do you think you could open the window? } \\
\text { Would you mind opening the window? }\end{array}$ \\
\cline { 3 - 4 } & \multirow{3}{*}{ Softeners } & Understatement & Could you open the window for a moment? \\
\cline { 3 - 4 } & & Downtoner & Could you possibly open the window? \\
\cline { 2 - 3 } & &
\end{tabular}




\begin{tabular}{|c|c|c|c|}
\hline \multirow{6}{*}{$\begin{array}{l}\text { Internal } \\
\text { Modification }\end{array}$} & & Hedge & Could you kind of open the window? \\
\hline & Intensifiers & & $\begin{array}{l}\text { You really must open the window } \\
\text { I'm sure you wouldn't mind opening the } \\
\text { window }\end{array}$ \\
\hline & & Hesitators & $\begin{array}{l}\text { I er, erm, er } \\
\text { I wonder if you could open the window }\end{array}$ \\
\hline & Fillers & Cajolers & You know, you see, I mean \\
\hline & & Appealers & OK?, Right?, yeah \\
\hline & & Attention-getters & $\begin{array}{l}\text { Excuse me ...; Hello ...; Look ...; Tom , ...; Mr. } \\
\text { Edwards ...; father ... }\end{array}$ \\
\hline \multirow{6}{*}{$\begin{array}{l}\text { External } \\
\text { Modification }\end{array}$} & Preparators & & $\begin{array}{l}\text { May I ask you a favour? } \\
\text { Could you open the window? }\end{array}$ \\
\hline & Grounders & & $\begin{array}{l}\text { It seems it is quite hot here. Could you open the } \\
\text { window? }\end{array}$ \\
\hline & Disarmers & & $\begin{array}{l}\text { I hate bothering you but could you open the } \\
\text { window? }\end{array}$ \\
\hline & Expanders & & $\begin{array}{l}\text { Would you mind opening the window? ... Once } \\
\text { again, could you open the window? }\end{array}$ \\
\hline & $\begin{array}{l}\text { Promise of } \\
\text { reward }\end{array}$ & & $\begin{array}{l}\text { Could you open the window? If you open it, I } \\
\text { promise to bring you to the cinema. }\end{array}$ \\
\hline & Please & & Would you mind opening the window, please? \\
\hline
\end{tabular}

Table 2: Typology of peripheral modification devices in requests (ALCÓN et al., 2005)

\begin{tabular}{|l|l|}
\hline FACTORS & POLITENESS EFFECT \\
\hline Social distance & Social distance increases $\rightarrow$ Politeness increases \\
\hline Power & Power increases $\rightarrow$ Politeness increases \\
\hline Imposition & Imposition is great $\rightarrow$ Politeness increases \\
\hline
\end{tabular}

Table 3: Based on Brown and Levinson (1987)

The study involved 20 students, all of them enrolled in the Degree in Translation at the university. Their ages ranged from 18 to 30 years old, the average age being 22.1 years. Participants did not show any statistically significant differences in their level of proficiency in English, as measured by the university entrance exam they were required to pass in order to enrol on the translation degree. In addition, participants did not differ to any significant extent with regard to ethnicity or academic background. Two lecturers also participated in the study. While one of them focused on teaching requests during two-hour sessions held every week for 6 weeks the other observed the lesson in order to 
indicate (should it be the case) any bias shown by the instructor for or against pragmatic instruction. In addition, learners were trained to use AlfraCovalt in their language classroom. Alfracovalt is a querry program that processes two corpora: the Auvi corpus and the COVALT corpus. Auvi is a corpus adhoc created and build with tv series like Stargate SG-1 (with 94 episodes, of one hour), The Berenstain Bears (a cartoon serie of 40 episodes of half an hour each), and the movie Two can play that game (2001), directed by Mark Brown (a total of 116 hours of audiovisual input). English is the language of the original texts, which are translated into Catalan for the Valencian Tv. On the other hand the corpus COVALT (GUZMAN; SERRANO, 2006) is build with full texts of narrative works and their translations into Catalan and Spanish published by Valencian press between 1990 and 2000 (204 works). As far as the interface is concerned, the Alfracovalt program has embedded a sentence alignment algorithm. It is a querry program that searches concordances between parallel texts using lexical information and certain heuristics. These searches can be carried out in the original text or in the translated text. Basically the program works with internal and external sources. The external sources are three Access databases, each database with two fields, the first one with Catalan lemmatised words and the second one with the equivalence lemmatised word in English, French or German. All of them indexed and with duplicates. The German database has 54.581 entries, the English one 45.399 and the French one 73.474. The internal sources are Paradox databases with the texts' splitting sentences. The texts are split with a multilingual sentence boundary disambiguation algorithm using regular expressions (GUZMAN; MIQUEL, in press) and saved as registers in the Paradox databases. After typing the search string the alignment algorithm looks for the sentences where that string is embedded. The selected sentence (S1) will be tokenised, and each token lemmatised. A SQL query searches into the Access Database (depending on the languages involved, the English, German or French Database) for the lemmas' translation, and then into the translated (or original) text looking for the sentences with the same words, of course with the morphological changes needed. So, in order to reduce time and economise resources, this search is done in a small window of the target text. This process is based on the idea that there is a relationship between the text length in terms of characters and the position of the searched string in both texts, original and translated. If the number of words found in a sentence of the target text (S2) is greater than five and its percentage is $20 \%$ greater than 
the words in $\mathrm{S} 2$, then we can say that $\mathrm{S} 1$ and $\mathrm{S} 2$ are equivalent. If any of these conditions are negative, then the query continues with the sentences before and after the sentence analysed. At the end, the program returns the concordances between both texts (OT and TT) as shown in Figure 1.

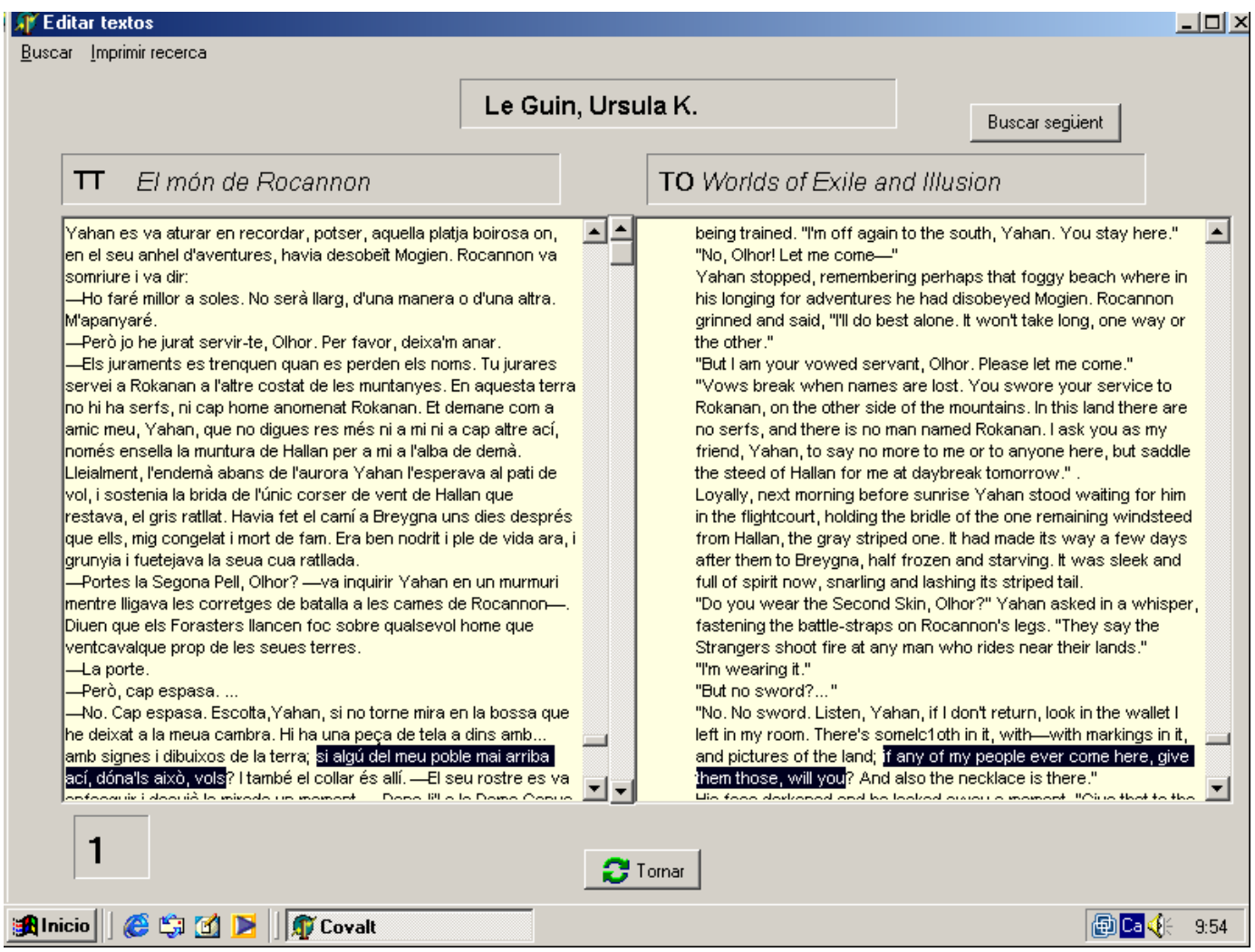

Figure 1: Concordances example

The following procedure was used with the aim of raising learners' awareness of requests:

1) Searching for requests in the original version

2) A comparison of the original version with the one provided by means of AlfraCovalt by focussing on the following pragmalinguistic question: How many forms of requests modifiers did you find in the original version? Are they translated literally? If not, write down the equivalent.

"Would you mind telling me, Agatha, what it was that you dreamed about me?" (A. C. Doyle, The parasite) 
"[...] et faria res contar-me què has somiat de mi?"

"BROTHER (delicately) Would you mind if I took that book? I left it here by mistake. (The Berenstain Bears "Think of those in need" EPISODE 29A)"

GERMÀ (DE) Li importa que m'emporte este llibre? Me l'he deixat ací per error.

3) A comparison of the OT and TT to check if there is any difference in the quantity and type of request modifiers. If so, why?

a) "My dear sir," said Mr. Otis, "I really must insist on your oiling those chains, [...] “(O. Wilde, Lord Arthur Savile's Crime)

Estimat senyor meu- digué el senyor Otis-, francament he d'insistir que greixe les cadenes

b) SQUIRE (partly OS) I'm going to need your skills. You see, I need a gift for my wife's birthday. I'd like you to build her a very special chair. (The Berenstain Bears, "The hiccup cure" EPISODE 29B)

MONOCLE Necessitaré de les teues habilitats. Mira, voldria un regal per a l'aniversari de la meua dona. (ON/OFF) M'agradaria que li construïres una cadira molt especial.

c) QUILTER \#1 (to Brother) Thank you for the lemonade, Dear. (then to Sister) You know, my eyes aren't what they used to be. Do you think you could thread my needle for me? (The Berenstain Bears, "Trouble with money” EPISODE 6A

TEIXIDORA Gràcies per la llimonada, bonico. / Filla, amb l'edat he perdut molta vista.(OFF) Creus que podries enfilar-me l'agulla?

d) O'NEILL: Oh, stop it, will you? (STARGATE SG-1 "Abyss" EPISODE \#P653)

O'NEILL: Ai, deixa-ho ja, per favor.

e) BROTHER Huh. You'll never let me forget that, will you? (The Berenstain Bears "The talent show" EPISODE 9A)

GERMA: (G) No se t'oblidarà mai, veritat?

f) "Shut the door so that it don't fly open, will you? I can't stand a door banging. They've put a lot of rubbishy locks into (J. Conrad, Typhoon)

Tanque la porta de manera que no s'óbriga, vol?

g) "Just hand over that sapphire cross of yours, will you? (G. K. Chesterton, The secret garden)

Done'm ara mateix la seua creu de safirs, entesos? 
4) Teachers' explanation of the typologies in Tables 1 and 2 with presentation of request head acts and the internal and external modification devices accompanying them in OT and TT are provided.

5) Teachers' explanation on the effect of sociopragmatic factors on politeness is provided.

6) An analysis of requests in OT and the TT to examine whether the linguistic realizations of the speech act of requesting is influenced by sociopragmatic factors such as degree of familiarity, interlocutors' power or size of the request.

The above mentioned procedure enables teachers to guide learners' attention to some linguistic formulae requests that are given and received in different languages, and how different realization strategies are used, taking into account social factors such as interlocutors' power, familiarity or status. These observation tasks based on translations may help students make connections between linguistic forms, pragmatic functions, their occurrence in different social contexts, and their cultural meanings. In other words, students are guided to notice the information they need in order to develop their pragmatic competence in L2. Thus, we can claim that translation offers foreign language learners the opportunity to reflect on different pragmatic options in a communicative event. In addition, by encouraging students to explore and reflect their experiences, observations, and interpretations of translations as communication across cultures we might gain a better understanding of the meaning in the original text.

\section{References}

ALCÓN, Eva. Desarrollo de la competencia discursiva oral en el aula de lenguas extranjeras: perspectivas metodológicas y de investigación. In: Muñoz, C. (Ed.). Segundas lenguas: adquisición en el aula. Barcelona: Ariel, 2002. p. 259-272.

ALCÓN, Eva. Does instruction work for learning pragmatics in the EFL context? System, vol. 3, p. 417-435, 2005.

ALCÓN, Eva; SAFONT, Maria P.; MARTÍNEZ-FLOR, Alicia. 2005. Towards a typology of modifiers for the speech act of requesting: a socio-pragmatic approach. 
RAEL: Revista Electrónica de Lingüística Aplicada, vol. 4, p. 1-35, 2005.

ALCÓN Eva, SAFONT, Maria. P. Pragmatic awareness in second language acquisition. In: CENOZ, Jasone; HORNBERGER, Nancy H. (Eds.). Encyclopedia of language and education, vol. 6, Knowledge about language. 2 ed. New York: Springer, 2008.

BACHMAN, Lyle F. Fundamental considerations in language testing. Oxford: Oxford University Press, 1990.

BARDOVI-HARLIG, Kathleen. Evaluating the empirical evidence: grounds for instruction in pragmatics. In: ROSE, Kenneth R.; KASPER, Gabriele. (Eds.). Pragmatics in language teaching. Cambridge: Cambridge University Press, 2001. p. 1332.

BARDOVI-HARLIG, Kathleen; DÖRNYEI, Zoltan. Do language learners recognize pragmatic violations? Pragmatic versus grammatical awareness in instructed L2 learning. TESOL Quarterly, vol. 32, n. 2, p. 233-259, 1998.

BARDOVI-HARLIG, Kathleen; HARTFORD, Beverly. Input in an institutional setting. Studies in Second Language Acquisition, vol. 18, n. 2, p. 171-190, 1996.

BROWN, Penelope; LEVINSON, Stephen. C. Politeness: some universals in language usage. Cambridge: Cambridge University Press, 1987.

CANALE, Michael. From communicative competence to communicative language pedagogy. In: RICHARDS, Jack. C.; SCHMIDT, Richard W. (Eds.). Language and communication. London: Longman, 1983. p. 2-27.

CANALE, Michael; SWAIN, Merril. Theoretical bases of communicative approaches to second language teaching and testing. Applied Linguistics, vol. 1, p. 1-47, 1980.

CELCE-MURCIA, Marianne; DÖRNYEI, Zoltán.; THURRELL, Sarah. Communicative competence: a pedagogically motivated model with content specifications. Issues in Applied Linguistics, vol. 6, p. 5-35, 1995.

COOK, Misty; LIDDICOAT, Anthony J. 2002. The development of comprehension in interlanguage pragmatics: the case of request strategies in English. Australian Review of Applied Linguistics, vol. 25, 19-39.

CRYSTAL, David. (Ed). The Cambridge encyclopedia of language. 2 ed. New York: Cambridge University Press, 1997.

FELIX-BRASDEFER, J. César. Interlanguage refusals: linguistic politeness and length of residence in the target community. Language Learning, vol. 54, n. 4, p. 587-653, 2004.

GARCÍA, Paula. Pragmatic comprehension of high and low level language learners. Teaching English as a Second or Foreign Language, vol. 8, p. 1-10, 2004. 
GOODWIN, Charles.; DURANTI, Alessandro. Rethinking context: an introduction. In: DURANTI, Alessandro, GOODWIN, Charles. (Eds.). Rethinking context: language as an interactive phenomenon. Cambridge: Cambridge University Press, 1992. p. 1-42.

GRANT, Lynn.; STARKS, Donna. Screening appropriate teaching materials. Closings from textbooks and television soap operas. International Review of Applied Linguistics, vol. 39, p. 39-50, 2001.

GUZMAN PITARCH, Josep R.; SERRANO, Alvar. Alineamiento de frases y traducción: AlfraCOVALT y el procesamiento de corpus. Sendebar, vol. 17, p. 169186, 2006.

GUZMAN PITARCH, Josep R.; MIQUEL, Francesc. In press. Splitting sentences for a parallel corpus using regular expressions.

HASSALL, T. J. Requests by Australian learners of Indonesian. Unpublished doctoral dissertation. Canberra: Australian National University, 1997.

HOUSE, Julianne. Forthcoming. Using translation and interpreting to increase L2 pragmatic competence. In: ALCÓN, Eva; MARTÍNEZ-FLOR, Alicia. Investigating pragmatics in foreign language learning, teaching and testing. Clevedon: Multilingual Matters.

HYMES, Dell. On communicative competence. In: PRIDE, John B.; HOLMES, Janet (Eds.). Sociolinguistics: selected readings. Harmondsworth: Penguin, 1972. p. 269-293.

JUNG, Ji-Yung. Issues in acquisitional pragmatics. Working papers in TESOL and Applied Linguistics, vol. 2, p. 1-34, 2002.

KASPER, Gabriele. Pragmatic comprehension in learner-native speaker discourse. Language Learning, vol. 34, p. 1-20, 1984.

KOIKE, Dale A. Pragmatic competence and adult L2 acquisition. Speech acts in interlanguage. Modern Language Journal, vol. 73, n. 3, p. 79-89, 1989.

KOIKE, Dale. A. Transfer of pragmatic competence and suggestions in Spanish foreign language learning. In: GASS, Susan M.; NEU, Joyce (Eds.). Speech acts across cultures: challenges to communication in a second language. New York: Mouton de Gruyter, 1996. p. 257-281.

LEECH, Geoffry. The principles of pragmatics. London: Longman, 1983.

LEVINSON, Stephen. Pragmatics. Cambridge: Cambridge University Press, 1983.

LI, Duanduan. The pragmatics of making requests in the L2 workplace: a case study of language socialization Canadian Modern Language Review, vol. 57, n. 1, p. 58-87, 2000 . 
LOCASTRO, Virginia. An introduction to pragmatics: social action for language teachers. Michigan: Michigan Press, 2003.

LORENZO-DUS, Nuria. Compliment responses among British and Spanish university students: a contrastive study. Journal of Pragmatics, vol. 33, p. 107-127, 2001.

MÁRQUEZ-REITER, Rosina. Linguistic politeness in Britain and Uruguay. A contrastive studies of requests and apologies. Amsterdam: John Benjamins, 2000.

MARTÍNEZ-FLOR, Alicia. Forthcoming. The effect of an inductive-deductive teaching approach to develop learners' use of request modifiers in the EFL classroom. In: ALCÓN, Eva (Ed.). Learning how to request in an instructional language learning context. Bern: Peter Lang.

MARTÍNEZ-FLOR, Alicia.; USÓ-JUAN, Esther. Learners' use of request modifiers across two University ESP disciplines. Ibérica, vol. 12, p. 23-41, 2006.

NIEZGODA, Kimberly; RÖVER, Carsten. Pragmatic and grammatical awareness. In: ROSE, Kenneth. R.; KASPER, Gabriele. (Eds.). Pragmatics in language teaching. Cambridge: Cambridge University Press, 2001. p. 63-79.

OLSHTAIN, Elite; BLUM-KULKA, Shoshana. Degree of approximation: nonnative reactions to native speech act behaviour. In: GASS, Susan; MADDEN, Carolyn. (Eds.), Input in second language acquisition. Rowley, MA: Newburry House, 1985. p. 303325.

ROSE, Kennth R.; NG, Kwai-Fong. Inductive and deductive teaching of compliments and compliment responses. In: ROSE, K. R.; KASPER, Gabriele. (Eds.). Pragmatics in language teaching. Cambridge: Cambridge University Press, 2001. p. 145-170.

ROSE, Kennth R. An exploratory cross-sectional study of interlanguage pragmatic development. Studies in Second Language Acquisition, vol. 22, p. 27-67, 2000.

SAFONT, Maria. P. Forthcoming. The speech act of requesting. In: ALCÓN, Eva. (Ed.). Learning how to request in an instructional language learning context. Bern: Peter Lang.

SAFONT, Maria. P. Third language learners: pragmatic production and awareness. Clevedon: Multilingual Matters, 2005.

SCHMIDT, Richard. Consciousness, learning and interlanguage pragmatics. In: KASPER, Gabriele.; BLUM-KULKA, Shoshana. (Eds.). Interlanguage pragmatics. New York, Oxford University Press, 1993. p. 21-42.

SCHMIDT, Richard. Attention. In: ROBINSON, Peter (Ed.). Cognition and second language instruction. New York: Cambridge University Press, 2001. p. 3-33.

SCOLLON, Ron; SCOLLON, Suzie. Wong. Intercultural communication : a discourse approach. Oxford: Blackwell, 1995. 
SIFIANOU, Maria. Politeness phenomena in England and Greece: a cross-cultural perspective. Oxford: Oxford University Press, 1999.

TAKAHASHI, Satomi. Pragmatic transferability. Studies in Second Language Acquisition, vol. 18, p. 189-223, 1996.

THOMAS, Jenny. Cross-cultural pragmatic failure. Applied Linguistics, vol. 4, p. 91$112,1983$.

WASHBURN, Gay N. Using situation comedies for pragmatic language teaching and learning. TESOL Journal, vol. 10, n. 4, p. 21-26, 2001. 